\title{
Role of the Public Sector in Agricultural Coopetition: Place-based Marketing in Post-WTO Rural Taiwan
}

\author{
Herlin Chien $^{1}$ \\ ${ }^{1}$ Department of International Affairs, Wenzao Ursuline University of Languages, Kaohsiung, Taiwan \\ Correspondence: Herlin Chien, Assistant Professor, Department of International Affairs, Wenzao Ursuline \\ University of Languages, No 900 Sec. 1 Mintsu Road, Kaohsiung, Taiwan. Tel: 886-7-342-6031.
}

Received: February 1, 2016

Accepted: February 10, 2016

Online Published: February 12, 2016

doi:10.5430/jms.v7n1p65

URL: http://dx.doi.org/10.5430/jms.v7n1p65

\begin{abstract}
Since the Uruguay round, the trend of liberalization in agricultural trade has been unstoppable. Although countries were eager to become members of the World Trade Organization (WTO) after the 1990s, agricultural production, trade and consumption patterns have also been undergoing rapid changes both in developed and developing regions. How have governments in different countries reacted to these changing realities and challenges? In addition to practicing conventional protectionism, such as farm subsidies and tariff wars to sustain the domestic agricultural industry, what else can the public sector do to reform agriculture? This research studied four public-private partnership cases in southern Taiwan to demonstrate an alternative governmental response to the changing agricultural trade, where the public sector induces competing farmers to cooperate. Specifically, the government encouraged the farmers in rural communities to engage in a so-called "state-led coopetition" strategy to promote place-based marketing and collectively create a competitive advantage in the post-WTO era. The research focuses on why and how competing farmers cooperate and the impact of state intervention on coopetition.

In terms of research contribution, this study first addresses the theoretical and empirical deficiencies in discussing the role of the public sector in coopetition strategy. Second, after a careful examination of the motivation, implementation and outcome in the four state-led coopetition cases, four major findings are identified to advance coopetition theory building. These findings are the following: 1) crises are focusing events that induce coopetition behavior; 2) competing firms in state-led coopetition cooperate and compete differently than in a typical business environment; 3) not all coopetition that is led by the public sector is unintentional; and 4) state-led coopetition generates extra public value.
\end{abstract}

Keywords: coopetition, PPP, agriculture, crisis, public value, public sector

\section{Introduction}

The Uruguay round has been called the largest and most important set of multilateral trade negotiations ever undertaken in human history, with more than 123 countries participating as contracting parties from 1986 to 1994. The impact of the Uruguay round has also been far-reaching for world growth in many aspects (Schott \& Buurman, 1994; Martin, 1996; Harrison et al., 1997). One of these aspects is the unstoppable trend of liberalization in agricultural trade since the creation of the World Trade Organization (WTO) (Hathaway \& Ingco, 1995). Although countries have been eager to become members of the WTO since the 1990s, agricultural production, business models and consumption patterns have also been undergoing rapid changes both in developed and developing regions. How have governments in different countries reacted to these changing realities and challenges in agriculture (McNiel, 1997; Potter \& Burney, 2002; Moss \& Bannon, 2004; Naoi \& Kume, 2011)? In addition to practicing conventional protectionism, such as farm subsidies and tariff wars to sustain the domestic agricultural industry, what else can the public sector do to reform agriculture?

In this age of cross-border market liberalization in a highly competitive environment, a "revolutionary mindset" may be needed to find a way out of the stalemate. Brandenburger and Nalebuff offered the "coopetition" strategy in 1997 as a novel conceptual lens to examine the business world differently and reshape the competitive environment 
favorably (Note 1). Can "coopetition" be a possible solution to address the challenges that are faced in the reshaping of the agricultural industry? Why and how should farmers cooperate in an uncooperative environment? What is the role of the public sector in coopetition? What is the impact of state-led coopetition?

To respond to these questions, this research studies four rural communities in southern Taiwan to demonstrate an alternative response to the changing agricultural trade, where local governments induce competing farmers to cooperate. Farmers from these rural communities were encouraged by the public sector to engage in a so-called "state-led coopetition" strategy and public-private partnership programs to promote place-based marketing and collectively create a competitive advantage after Taiwan's accession to the WTO in 2002.

This paper first addresses the theoretical and empirical deficiencies in discussing the role of the public sector in coopetition strategy. After introducing the case selection and method, the subsequent analysis examines 1) motivation, 2) implementation, and 3) outcome of state-led coopetition. The following four major findings are identified to advance coopetition theory building: 1) crises are focusing events that induce coopetition behavior; 2) competing firms in state-led coopetition cooperate and compete differently than in a typical business environment; 3 ) not all coopetition led by the public sector is unintentional; and 4) state-led coopetition generates extra public value.

\section{Discussion on Role of Public Sector in Coopetition Strategy}

Currently, pure competition or cooperation can no longer fully describe firm behavior. To compete effectively, building coopetition strategies or inter-organizational relations is becoming a recipe to succeed. Since the 1980s, scholars have begun to theorize how partnerships are strategically formed by cooperation among competitors to collectively achieve a competitive advantage (Hamel et al., 1989; Contractor \& Lorange, 1988; Jorde \& Teece, 1989). Researches have also noted the potential of coopetition or the coexistence of cooperation and competition in knowledge creation and innovation for firms (Ritala et al., 2009). Although competition can prevent narrow views and enhance value differentiation (Kusunoki, 2004), cooperation helps to bring in non-redundant knowledge and ideas from external actors (Inkpen, 1996; Ellinger, 2000). Combining both competition and cooperation creates the so-called "syncretic rents" (Lado et al., 1997).

Empirically, numerous case studies such as Dell and IBM's collaboration (Albert, 1999) and SAP with Oracle (Cringely, 2002) demonstrate their coopetition success. In addition to the high-tech industry, coopetition strategy has also been applied in traditional industries such as between competing ports (Juhel, 2000). Coopetition also revived a dying Toronto-based gold-mining firm, Goldcorp, whose CEO saw things differently by switching the rules of the game from a purely competitive to a collaborative approach (Tapscott \& Williams, 2006).

However, although most of these coopetitions are intentional, scholars distinguish between deliberate and emergent coopetition strategies where external actors such as the public sector can play a role (Mintzberg, 1978; Mintzberg \& Waters, 1985; Bengtsson \& Kock, 2000). Mariani (2007) used evidence from Australian and Italian operas to show how both coopetition and cooperation can result from an unintended strategy process that is induced by the external institutional environment. Mariani's research introduced a new term, "induced coopetition", to describe how the institutional environment (Astley \& Fombrun 1983) - in this case, the Tuscany Regional Council - induces coopetitive strategic behaviors among the three competing Italian opera houses. Mariani's research indirectly showed the influence of the public policymaker on firm or inter-firm behavior. In Thailand, Mongkhonvanit (2014) discussed how coopetition among the "triple helix" - academia, industry and government - can nurture networks of resources, energies and talents to create a new model of economic development and increase regional competitiveness. Except for these studies in the extant literature, the theoretical discussions on the role of the public sector in crafting coopetition strategies are scarce and often confined to the tourism sector (Boivin, 1987; Stevens, 1988). Kylänen and Rusko (2011) used the service industry case in Finnish tourism destinations to illustrate intentional and unintentional coopetition between the public sector and firms. Baggio et al. (2013) discussed how government is needed to provide the vital elements to the tourism destination product by bringing competing actors together and coordinating resources. Selin and Chavez (1995) showed the necessity of an evolutionary tourism of public-private partnership in destination management to create synergy in a competing environment.

\section{Case Selection and Method}

To enrich the theoretical and empirical discussions on the role of the public sector in coopetition, this research conducted a series of in-depth interviews and archival data collection in four rural communities in Kaohsiung in 
southern Taiwan to study competitors' cooperating behavior that is induced by public-private partnership programs. By analyzing the state-led agricultural coopetition cases, this study explores the following: 1) under what conditions competing firms - or in this case, farmers - are induced by the government to cooperate; 2) the role of the public sector in changing the rules from a zero-sum game to a variable-sum game in rural towns; and 3) the type of impact that state-led coopetition has on the community.

The four rural communities in southern Taiwan were selected to study the role of government in coopetition for several reasons. First, since Taiwan joined the WTO in 2002 and became the 144th member, the impact of trade liberalization on the agricultural sector has been significant. Trade liberalization has caused a $20 \%$ reduction in subsidies, an influx of imported agricultural products with lower customs taxes (Note 2) and an estimated 100,000 jobs lost in the agricultural sector (Wang, 2002). Only a few months after Taiwan's accession to the WTO, the "1123 Coexist with Farming" parade occurred on November 23, 2002. This parade was one of the largest farmers' social movements, and more than 120,000 farmers and fishermen, who were organized by the National Farmers and Fishermen Associations, joined the rally (Ting, 2011). To restructure and transform Taiwan's agricultural sector is not easy because of its aging farming population, relatively small farm production, higher production costs, climate change-related disasters in recent years, etc. (Huang, 2008; Ma \& Chuan, 2008). Government intervention to find cooperative solutions in uncooperative environments in these circumstances has become a request from the people and an urgent task.

Second, southern Taiwan, including the Tainan, Kaohsiung and Pintung areas, is the traditional agricultural production base and home to approximately $30 \%$ of all agricultural employees (Chu, 2001) in Taiwan. The cases that are chosen from these regions can better reflect the realities and challenges that Taiwan's agricultural industry faces and the response, involvement and impact of the public sector. Third, the four communities' cases were recommended by the Agricultural Bureau of the Kaohsiung city government. These cases exemplify the government's efforts since 2013 to enhance local agricultural production in the post-WTO era through Taiwan's first year-round public-private agritourism partnership program called "One Day Farmer" (Note 3). As of 2015, this public-private partnership program has operated in more than 15 agricultural districts in Kaohsiung, which includes 37 rural revitalized communities. Every year, more than 20,000 tourists participate in the program among which $80 \%$ are from Mainland China (Note 4). The success of this unique public-private partnership model has also been discovered by other public and private actors who intend to implement similar programs in other cities and counties in Taiwan. These programs include Yunlin County, the Gukeng one-day coffee farm tour (Note 5) that is organized by a local leisure farm development association, and the rice paddy field one-day experience that was organized by a private company called "Niceday" (Note 6).

The background of the four selected state-led "One Day Farmer" coopetition cases is shown in Table 1. All four cases are located in a rural area of metropolitan Kaohsiung City - the second largest city in Taiwan with a population of 2.7 million people. Case 1 is the Jhong-zun community in the Meinong District. The Meinong District has a population of 40,000 people in which the Hakka ethnic minority has been the majority in this water abundant region since 1698 (Note 7). The major agricultural products used to be rice, pork and tobacco leaves. Under the coordination of the Meinong Farmers' Association, a semi-governmental organization that was established in 1919, the public and private entities in the Meinong District began to launch place-based marketing efforts five years ago. This marketing was designed to promote new local brands and specifically, the production and sale of a unique species of small yellow tomato, which is registered as an "orange-flavored tomato", and the already registered "white jade radish". 
Table 1. State-led "one day farm" coopetition background

\begin{tabular}{|c|c|c|c|c|}
\hline & Case 1 & Case 2 & Case 3 & Case 4 \\
\hline & Meinong District & Dashu District & Cishan District & Cishan District \\
\hline & $\begin{array}{l}\text { Jhong-zun } \\
\text { community }\end{array}$ & $\begin{array}{l}\text { Nong-mu } \\
\text { community }\end{array}$ & $\begin{array}{l}\text { Jhong-liao } \\
\text { community }\end{array}$ & Nan-sheng community \\
\hline \multirow{3}{*}{$\begin{array}{l}\text { Featured } \\
\text { agricultural } \\
\text { product }\end{array}$} & Tomato and Radish & Pineapple & Yellow Ginger & Lychee \\
\hline & $\begin{array}{l}\text { "Orange-flavored } \\
\text { Tomato" and }\end{array}$ & $\begin{array}{l}\text { "Gold-Diamond } \\
\text { Pineapple" }\end{array}$ & "Fiberless Ginger" & "Jade Purse Lychee" \\
\hline & "White Jade Radish" & & & \\
\hline \multirow[t]{7}{*}{ Background } & - Small farm & - Large farm & - Small farm & - Small farm \\
\hline & $\begin{array}{l}\text { - Tomato and radish } \\
\text { production after }\end{array}$ & $\begin{array}{l}\text { - Most pineapple } \\
\text { farms in }\end{array}$ & $\begin{array}{l}\text { - Mountainous/ } \\
\text { remote areas }\end{array}$ & $\begin{array}{l}\text { - Very short harvest time, } \\
\text { within two weeks }\end{array}$ \\
\hline & $\begin{array}{l}\text { second season of } \\
\text { paddy rice in the fall }\end{array}$ & $\begin{array}{l}\text { Taiwan/agricultural } \\
\text { enterprises }\end{array}$ & - Urbanization, & $\begin{array}{l}\text { - Volunteers in } \\
\text { public-private }\end{array}$ \\
\hline & and winter seasons & - More farms are & community & partnership programs are \\
\hline & - Short-season crop & licensed to export & population & all farmers who did not \\
\hline & $\begin{array}{l}\text { - Hakka minority } \\
\text { cultural community }\end{array}$ & - Higher price for & - Community is in & time \\
\hline & & $\begin{array}{l}\text { processed } \\
\text { fruit-related } \\
\text { products }\end{array}$ & revitalization & $\begin{array}{l}\text { - Need to diversify } \\
\text { income source during } \\
\text { non-Lychee harvest time }\end{array}$ \\
\hline \multirow{7}{*}{$\begin{array}{l}\text { Content of } \\
\text { "One Day } \\
\text { Farm" } \\
\text { public-private } \\
\text { partnership } \\
\text { program }\end{array}$} & - Hakka cultural & \multirow{7}{*}{$\begin{array}{l}\text {-Community-guide } \\
\text { d tour } \\
\text { - Pineapple picking } \\
\text { - DIY pineapple } \\
\text { rice ball } \\
\text { - Native plant dye } \\
\text { experience }\end{array}$} & \multirow{7}{*}{$\begin{array}{l}\text { - Ginger farm tour } \\
\text { - DIY marinated } \\
\text { ginger } \\
\text { - Mountain } \\
\text { camping experience } \\
\text { - Eco tour } \\
\text { owl/insect/turtle } \\
\text { watch }\end{array}$} & - Banana farm visit \\
\hline & appreciation & & & - DIY pineapple dessert \\
\hline & - Hakka cuisine & & & - Lychee tree farming \\
\hline & - DIY Straw man & & & experience \\
\hline & -Radish pulling & & & - DIY Lychee wood \\
\hline & competition & & & clocks \\
\hline & - Tomato farm & & & - Fruit picking \\
\hline
\end{tabular}

Source: Compiled by author

Case 2 is the Nong-mu community in the Dashu District, which has the most pineapple farmers in Taiwan. Pineapple farming in the Dashu District dates back as early as the Ching dynasty, when the community practiced the majority of pineapple canning during the Japanese colonial period (Note 8). Since the establishment of agricultural data registrars from 1998 to 2008, this region has had the largest volume of pineapple production in the country. The Nong-mu community, in particular, began to develop organic pineapple farming in 2008 to allow the soil to return to its original natural state. Because of the Qingming festival in April, the region is famous for its Tainon NO 17, the so-called "gold-diamond pineapple". Since 2003, the Kaohsiung city government has joined with the Dashu Farmers' Association to host the annual Pineapple-Lychee Cultural Festival between May and June, with more than 100,000 visitors annually (Huang, 2009).

The Jhong-liao community and the Nan-sheng community are the third and fourth chosen cases. These communities are both located in the Cishan District but have different types of geographical characteristics and featured agricultural products. On the 300 meter high terrain of Jhong-liao, a special type of yellow ginger, known as "fiberless ginger," grows well and yields 60 tons of production annually (Note 9); in this region, the rich biodiversity is well-preserved and undisturbed. The Nan-sheng community, however, is inhabited mostly by small lychee farmers, with "Jade Purse lychee" as their place-based branding product. Moreover, because of the short harvest and sale time, which is usually less than one month, the Nan-sheng community began to diversify their products to create lychee-related processed foods and accessories such as lychee sausages and lychee wood clocks. 
To explore the public-private partnership efforts in promoting agricultural coopetition in the post-WTO era in Kaohsiung, this research interviewed a total of 16 interviewees. These interviewees included the principle coordinator in the Kaohsiung city government, Bureau of Agriculture, Rural Development Division, and 3-4 local farmers and community leaders per case (see the details in Table 2).

Table 2. Interviewee basic information

\begin{tabular}{|c|c|c|c|c|c|}
\hline & $\begin{array}{l}\text { Kaohsiung } \\
\text { City } \\
\text { Government }\end{array}$ & $\begin{array}{l}\text { Case 1 } \\
\text { Meinong } \\
\text { District } \\
\text { Jhong-zun } \\
\text { community } \\
\end{array}$ & $\begin{array}{l}\text { Case } 2 \\
\text { Dashu District } \\
\text { Nong-mu community }\end{array}$ & $\begin{array}{l}\text { Case } 3 \\
\text { Cishan District } \\
\text { Jhong-liao community }\end{array}$ & $\begin{array}{l}\text { Case } 4 \\
\text { Cishan District } \\
\text { Nan-sheng } \\
\text { community }\end{array}$ \\
\hline $\begin{array}{l}\text { \# of } \\
\text { Interviewees }\end{array}$ & 1 interviewee & $\begin{array}{l}3 \\
\text { interviewees }\end{array}$ & 4 interviewees & 4 interviewees & 4 interviewees \\
\hline Background & $\begin{array}{l}\text { Head of the } \\
\text { Bureau of } \\
\text { Agriculture } \\
\text { Rural } \\
\text { Development } \\
\text { Division }\end{array}$ & $\begin{array}{l}\text { - Jhong-zun } \\
\text { Village Head } \\
\text { - Leader, 8th } \\
\text { Vegetable } \\
\text { Production } \\
\text { and } \\
\text { Marketing } \\
\text { Group } \\
\text { - Secretary } \\
\text { General, } \\
\text { Farmers' } \\
\text { Association }\end{array}$ & $\begin{array}{l}\text { - Nong-mu Village } \\
\text { Head } \\
- \\
\text { Government-sponsored } \\
\text { youth staff from the } \\
\text { Agriculture } \\
\text { Revitalization Project } \\
\text { - President, Dashu } \\
\text { Agriculture Leisure } \\
\text { Area } \\
\text { - Small pineapple } \\
\text { farmer "Sunshine fruit" }\end{array}$ & $\begin{array}{l}\text { - Small ginger farmer/ } \\
\text { President, Community } \\
\text { Development } \\
\text { Association } \\
\text {-Jhong-liao Village } \\
\text { Head } \\
\text { - Village Secretary } \\
\text { General } \\
\text { - } \\
\text { Government-sponsored } \\
\text { youth staff from the } \\
\text { Agriculture } \\
\text { Revitalization Project }\end{array}$ & $\begin{array}{l}\text { - President and } \\
\text { Secretary } \\
\text { General of the } \\
\text { Nan-sheng } \\
\text { Community } \\
\text { Development } \\
\text { Community } \\
\text { - Lychee farmer } \\
\text { - Leader, } \\
\text { Lychee } \\
\text { Agricultural } \\
\text { Production and } \\
\text { Marketing } \\
\text { Group }\end{array}$ \\
\hline
\end{tabular}

Source: Compiled by author

The interviews were semi-structured, with a question outline that involved the condition, process and outcome of the public-private partnership programs. Special attention was directed at the coopetition dynamics in each community, the role that the public sector played in creating a cooperative environment and the benefits for competitors. The following three sections will present an analysis of the motivation, implementation and impact of these agricultural coopetition cases in sequence.

\section{Data Analysis}

\subsection{Motivation for State-let Coopetition}

Based on an analysis of the interviews and the collection of the archival data from the four rural communities, this study identifies two major motivational conditions for the public sector's successful support of agricultural coopetition in Kaohsiung, namely, crises and structural constraints. Regarding crises, the interviewees in three of the four communities described a background of crises that initiated coopetition (see Table 3). The crises coopetition-triggering effect is similar to how crises theoretically and empirically have impacted public policymaking (Kingdon, 1984; Birkland, 2006; Corbin, 2010). Birkland (1998) even called crises "focusing events" for policy change to emphasize their role as catalysts that affect policy agendas. Generally, crises represent an opportunity to take alternative action.

Concerning coopetition studies, crises prompt the alternative action of cooperating with long-time competitors with whom no alliances would be formed if there were no such crises. Of the four rural communities, Case 1 suffered the most from the crisis that related to Taiwan's accession to the WTO, with increasing imported rice competition from Japan and Korea. This crisis has been exacerbated by current negotiations on the Trans-Pacific Partnership (TPP) (Note 10) and the Regional Comprehensive Economic Partnership (RCET), the previous change of government regulation on water source protection and the end of the state monopoly sale mechanism for rice. Accordingly, this crisis has prompted the Meinong District to transform its agricultural industry by collectively planting and branding new agricultural products to compensate for the substantial economic losses. In Case 3, the Jhong-liao community, 
which is located in a mountainous area, was also hit by a crisis but in this case, a natural crisis. The entire community was nearly destroyed in 1977 by the Thelma typhoon, which has been called the largest destruction in Taiwan since World War II (Note 11). The residents evacuated the area and moved to the city; many of these residents have stayed there ever since. One elder interviewee recalled the loss of the population, which resulted in the closure of the elementary school that he attended in the 1950s, with 20-30 students in each class. He described the following:

"There were more than 100 households and around 600 residents in the 1950s...now we are 4/5 short, leaving only less than 200 residents.... I remember the abolishment of "Li" (village administrative zone) discussion in $1986 \ldots$ at that time, only 58 households were left...the district head raised a proposal to merge our community with nearby bigger communities...." (face-to-face interview on May 29, 2015 at the Jhong-liao Community Center).

In contrast, the interviewees in Case 2 exhibited a different perception of crisis and response compared with Cases 1 and 3. In 2003, when Taiwan suffered an island-wide severe acute respiratory syndrome (SARS) outbreak, the rumor that pineapple was effective in combating the virus spread quickly and consequently raised the price of pineapple from less than NT\$20 to more than NT\$100 each (Note 12). The interviewees also confirmed this rumor and admitted the direct benefit that reflected in their sales after 2003.

Table 3. Crises and structural constraints

\begin{tabular}{|c|c|c|c|c|c|}
\hline & & $\begin{array}{l}\text { Case } 1 \\
\text { Meinong District } \\
\text { Jhong-zun } \\
\text { Community }\end{array}$ & $\begin{array}{l}\text { Case } 2 \\
\text { Dashu District } \\
\text { Nong-mu } \\
\text { community }\end{array}$ & $\begin{array}{l}\text { Case } 3 \\
\text { Cishan District } \\
\text { Jhong-liao community }\end{array}$ & $\begin{array}{l}\text { Case } 4 \\
\text { Cishan District } \\
\text { Nan-sheng } \\
\text { community }\end{array}$ \\
\hline Crises & & $\begin{array}{l}\text { - After } 2002, \\
\text { post-WTO } \\
\text { imported rice } \\
\text { competition from } \\
\text { Japan and Korea } \\
\text { - Government } \\
\text { regulation change } \\
\text { - Need for } \\
\text { agricultural product } \\
\text { transformation }\end{array}$ & $\begin{array}{l}\text { - Used } 2003 \text { SARS } \\
\text { crisis as a benefit } \\
\text { to promote the } \\
\text { advantages of } \\
\text { eating pineapple }\end{array}$ & $\begin{array}{l}\text { - The } 1977 \text { Thelma } \\
\text { typhoon hit Kaohsiung, } \\
\text { destroyed many houses } \\
\text { and forced residents to } \\
\text { move to the city } \\
\text { - In 1986, only } 58 \\
\text { remaining households; } \\
200 \text { face the possible } \\
\text { abolishment of "Li" - } \\
\text { village administrative } \\
\text { title }\end{array}$ & None \\
\hline \multirow[t]{2}{*}{$\begin{array}{l}\text { Structu } \\
\text { ral } \\
\text { constra } \\
\text { ints }\end{array}$} & $\begin{array}{l}\text { Populatio } \\
\mathrm{n} \\
\text { structure }\end{array}$ & $\begin{array}{l}\text { Aging farming } \\
\text { population }\end{array}$ & $\begin{array}{l}\text { Less of an aging } \\
\text { problem/more } \\
\text { middle-aged } \\
\text { export } \\
\text { entrepreneurs }\end{array}$ & $\begin{array}{l}\text { Aging farming } \\
\text { population/population } \\
\text { loss }\end{array}$ & $\begin{array}{l}\text { Aging farming } \\
\text { population/ } \\
\text { younger } \\
\text { generation go to } \\
\text { the city for jobs } \\
\text { because of an } \\
\text { insufficient } \\
\text { agriculture-based } \\
\text { income }\end{array}$ \\
\hline & $\begin{array}{l}\text { Business } \\
\text { structure }\end{array}$ & $\begin{array}{l}\text { - Agricultural } \\
\text { product price is low } \\
\text { - Local market is } \\
\text { small }\end{array}$ & $\begin{array}{l}\text { - Existence of a } \\
\text { local market and } \\
\text { export market } \\
\text { - Higher demand } \\
\text { for processed fruit } \\
\text { - Higher price } \\
\text { expansion of the } \\
\text { export market } \\
\text { through scale } \\
\text { coopetition }\end{array}$ & $\begin{array}{l}\text { - Agricultural product } \\
\text { price is low } \\
\text { - Local market is small } \\
\text { - Use of ginger is } \\
\text { limited and usually in } \\
\text { small quantities }\end{array}$ & $\begin{array}{l}\text { - Only produced } \\
\text { once a year } \\
\text { - Short harvest } \\
\text { time } \\
\text { - Susceptible to } \\
\text { natural disasters }\end{array}$ \\
\hline
\end{tabular}

Source: Compiled by author 
In addition to crises, structural constraints were also found in the analysis to form the necessary conditions for competitors to change their competing behavior. Three of the four interviewed communities experienced severe population structural problems in the farming workforce. The exception is Case 2, which attracted some of the younger generation to return to the rural areas 10 to 20 years ago to expand the small farms to large farms that can obtain export licenses and generate higher incomes. With the profitable price of pineapple and the rising popularity of pineapple pie, the large pineapple farms in the Non-mu community could have each cultivated their own markets or even competed against one another. However, to make even greater profits and better secure future markets, placed-based marketing and a collective branding strategy became a need even for the large farmers. The other three rural communities experienced aging problems, relatively small farm production and limited local markets. For these communities, adjusting their trade behavior, learning to form partnerships with neighboring farms and other industries or simply seeking help from the government became critical to their survival before they could even compete.

\subsection{Implementation of State-led Coopetition}

In a typical business environment, scholars have argued that firms in a coopetitive relation frequently cooperate in the upstream activities and compete in the downstream activities (Nalebuff \& Brandenburger, 1997; Bagshaw \& Bagshaw, 2001; Wilkinson \& Young, 2002). Walley (2007) used the illustration that is shown in Figure 1 to explain the common form of a coopetition relation. Do the four state-led coopetition cases in Taiwan's agricultural sector conform to this common coopetition model? The analysis below will unravel this question in detail.

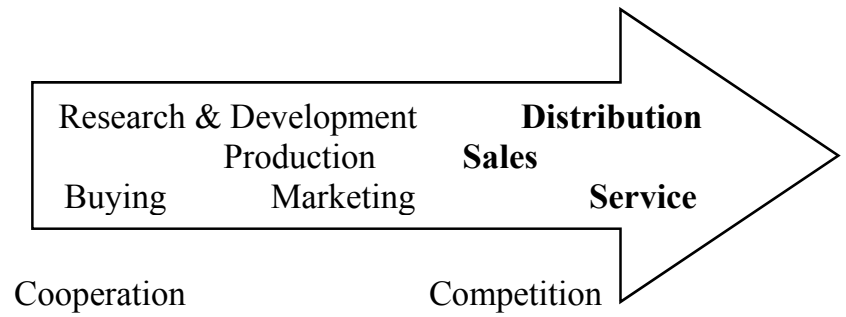

Figure 1. A common form of a coopetitive relation

*words in bold refer to downstream activities

Case 1 is a good example that does not conform to the common coopetition model in the extant literature (see Figure 2). Multiple crises as described in the last section have posed serious threats to the Meinong District's overall economic survival. The local Kaohsiung government joined with a pivotal semi-governmental agency in this community, the Meinong Farmers' Association, to centralize almost all of the production and sales cycles, including the initial seed choice, seed buying, research and development, production, distribution, marketing, etc. The public sector launched a series of place-based marketing strategies, for instance, registering trademarks under the Meinong Farmers' Association's name for their tomatoes and radishes with the unique names of "orange-flavored tomato" and "white jade radish" and hosting an annual white jade radish festival. The Kaohsiung City Bureau of Agriculture induces radish farmers to buy seeds from a single source to ensure quality control and the uniformity of the species before joining common distribution and sales, such as Post Mall (Note 13), which is also a state-owned e-commerce platform. Accordingly, the Kaohsiung City Bureau of Agriculture partially subsidizes the cost of seeds, requires a plantation registrar system, offers complimentary training in packaging, cleaning and grading agricultural products and grants priority rights to registered farmers for joining the "One Day Farm" public-private partnership program to add income from agritourism. The cooperation in Case 1 occurs in both the upstream and downstream activities, with little competition among farmers. 


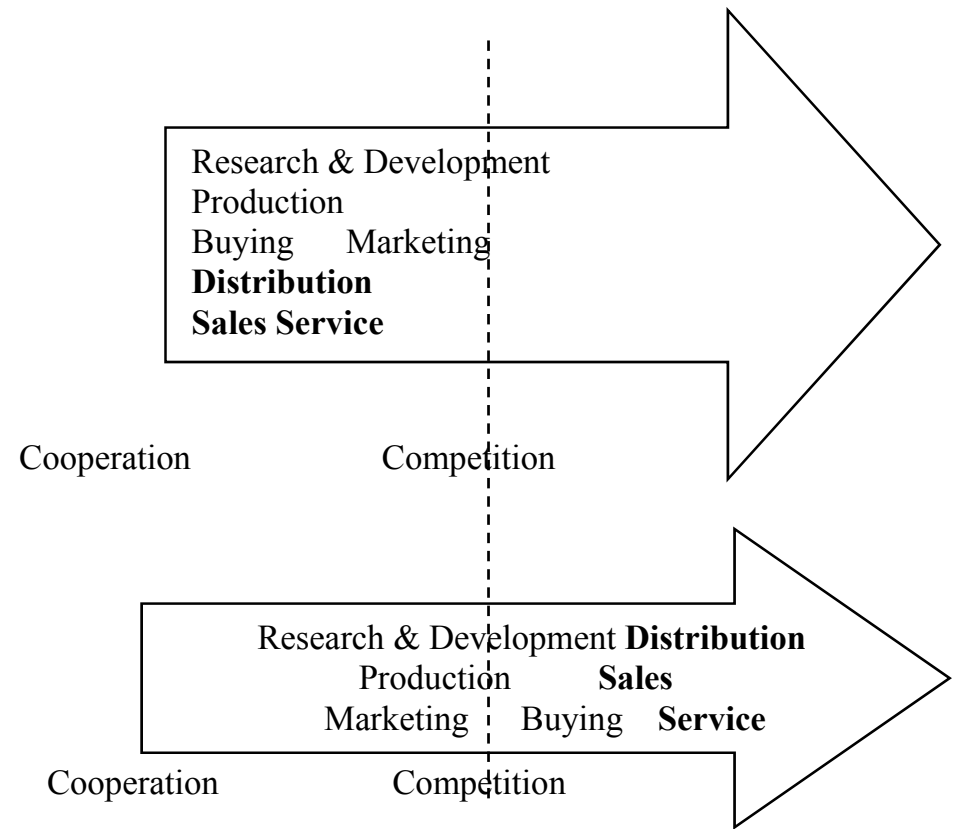

Figure 2. The coopetition relations of Case 1 Meinong compared with Case 2 Nong-mu

Case 2, however, exhibits a similar coopetition relation to the common model, with cooperation that focuses on the upstream activities. However, there are less cooperating motivations and needs, except for joining the place-based marketing activities to brand "gold-diamond pineapple" as the featured agricultural product from the Dashu District of Kaohsiung in the "One Day Farm" program. The booming pineapple export activities to China have already secured business profits for the large farms in this community. However, the agritourism that is coordinated and promoted by the Kaohsiung city government can allow Chinese consumers to visit the origin of their consumed product to further increase the product's international reputation and enhance the consumer's appreciation of agricultural produce.

In contrast, Cases 3 and 4 (see Figure 3) illustrate interesting cases of the common model, where most cooperation occurs in the downstream activities because of the small quantity of production in yellow ginger and the extremely short harvest and limited consumption expiration time of lychee. According to a leader in Case 4 of the Nan-shan Community Development Association:

"We want to create a brand for lychee grown in our community together... and we are building a common distribution/sales online platform with the cooperation of the Kaohsiung city government... common distribution can reduce the negative competition among the farmers in our community... but it is very difficult... because there are more than 20 different species of lychee and different modes of production in our community... but we want to use this advantage of species diversity to attract consumers. Consumers can taste various types of lychee in different growing seasons..." (face-to-face interview at the Nan-shan Community Center on May 8, 2015).

Case 4 is interested in building a common e-commerce platform for all lychees that are grown in the community, whereas Case 3 gives all of the community's "fiberless ginger" to a middle man or wholesaler for wider distribution to supermarkets or other channels. The quantity of ginger is so small that each farmer cannot distribute or sell it individually, except selling some ginger in traditional local markets. The cooperation dynamics, contrary to the common model, occur mainly in the downstream activities, with limited competition in production, buying and research and development. 


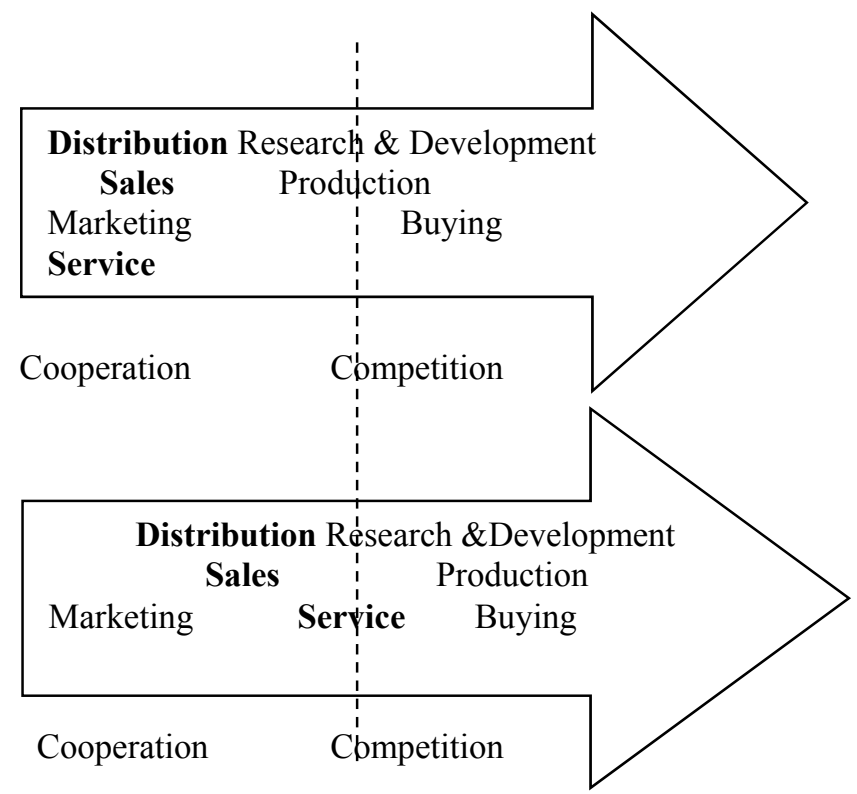

Figure 3. The coopetition relations of Case 3 Chun-lian compared with Case 4 Nan-shan

Regarding the temporal dimension of coopetition, Kylänen and Mariani (2012) introduced four different types of coopetition modes (see Figure 4). A type refers to long-term cooperation and short-term competition where cooperation prevails. B type indicates long-term cooperation and competition, and $\mathrm{C}$ type indicates short-term cooperation and competition; both types exhibit a balanced relation. D type represents long-term competition and short-term cooperation where competition prevails. After a careful analysis of the empirical cases, Case 3 and the radish production in Case 1 exhibit traits in quadrant $\mathrm{A}$. The yellow ginger and radish farmers engage in long-term cooperation activities by helping one another at harvest time, giving their agricultural products to wholesalers and promoting collectively; they only occasionally compete in the quality of their produce. An interviewee in Case 3 in the Chun-lian community explained the common practice of "ban pua," where community residents help one another to harvest ginger because of its large production yield during the short harvest time. She further commented that

“...we have less competition in our community... I think competition is often created by multiple species.... we only have one species... in the past, we each grew our own...but the sale was difficult...now, we are building a brand together, and the government helps us to create a logo to do sales as a group" (face-to-face interview on May 29, 2015).

The radish farm operation model in Case 1 is similar to the ginger farm in Case 3. However, in Case 1, the single species choice of radish is dictated by the public sector's place-based marketing strategy for quality control and branding purposes.

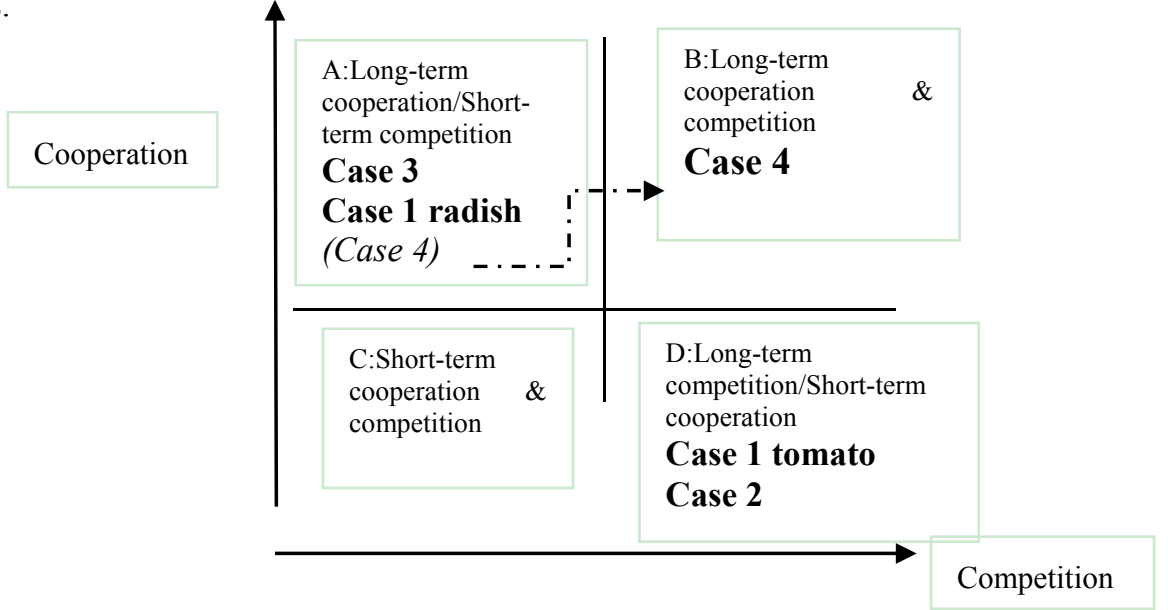

Figure 4. Temporal dimension of coopetition

Source: modified from Kylänen and Mariani, 2012 
Moreover, Kylänen and Mariani argued that these models are not necessarily static because each quadrant may represent a different stage in the lifecycle of competitive strategies (2012: 70). The coopetition evolution among lychee farmers in Case 4 can illustrate this shift of coopetition mode in different stages. In the initial stage of cooperation, the coordinator of the cooperative farming team hoped to achieve long-term cooperation with short-term competition (quadrant A). However, with more than 20 different lychee species that are grown in the same region, this interviewee also admitted that avoiding competition in the long term is difficult because there are more than 20 different species, and farmers' farming styles and techniques are not homogenous. For instance, some farmers refuse to undergo pesticide evaluation or "Good Agricultural Product" (GAP) monitoring mechanisms (May 8, 2015 face-to-face interview in the Nan-shan community). Therefore, the targeted short-term competition evolves to long-term competition, which makes Case 4 move from quadrant A to B.

Concerning Case 2, pineapples can sell for a good price, with a high demand in the processed food and export markets. Regarding Case 1, tomatoes can be easily marketed and packaged by individual farmers for e-commerce because of their small size and ease of conservation and consumption. Both agricultural products can survive and compete without cooperative programs. However, to maximum profits, farmers are still induced by local governments to engage in short-term cooperative activities (quadrant D).

Finally, if we investigate the nature of coopetition in these four cases, both intentional and unintentional types of coopetition can be identified. In traditional business strategy management, coopetition has been referred to as an explicit and rational strategy choice to achieve profits and maximize resources in the long term (Tidström, 2008; Thomason et al., 2013). However, Kylänen and Rusko (2011) used Finland's national park example to distinguish between intentional and unintentional coopetition at two different levels, namely, the strategic and operational levels, by proposing nine types of coopetition, which are shown in Table 4 . The strategic level refers to longer planning horizons that are usually undertaken by an external actor or resource coordinator such as provincial governments, municipalities or a Destination Management Organization (DMO), which is a semi-public development organization that promotes cooperation among competitors in the Pyhä-Luosto national park area. The operational level describes the actions of single, smaller firms or workers in a shorter timeframe. Applying the dichotomy of strategic and operational levels to the four agricultural coopetition cases, this study concurs with Kylänen and Rusko's observation. This study also finds that not all coopetition led by the public sector is unintentional, which is argued by former researchers who describe public institution-induced coopetition as "emergent coopetition" or "unintentional coopetition" (Mintzberg, 1978; Mariani 2007).

Table 4. Different forms of intentional and unintentional coopetition

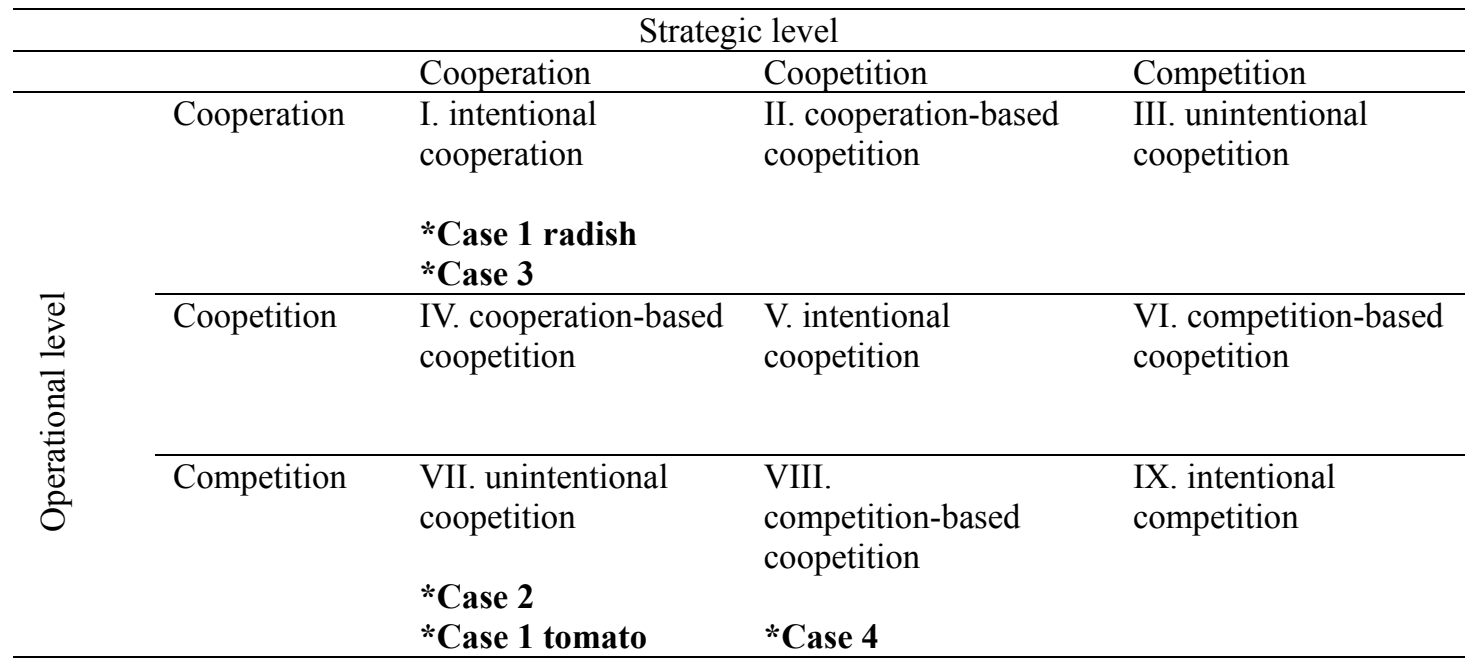

Source: Modified from Table 1 in Kylänen and Rusko (2011)

By analyzing the coopetition implementation process details that were provided by the interviewees in each community, Case 1 radish and Case 3 exhibit traits of "intentional cooperation" (State I in Table 4). At the strategic level, the local government launched an annual place-based marketing strategy by creating the annual "white jade radish festival" each winter. At the operational level, the radish farmers also complied with the rules that were 
established throughout the year by public institutions as a prerequisite to join the festival. The Meinong Farmers' Association and local district office in 2015 also decided to use the radish festival to compete against other festivals in the 2016 Hakka Village Twelve Festivals that were organized by the central government's Executive Yuan, Hakka Affairs Council (Note 14). Interestingly, in the same Meinong District, there are not only cooperative initiatives at the strategic level but also competitive actions at the operational level (State VII) in tomato production. Unlike radishes, $90 \%$ of tomato sales occur online. Each individual tomato farmer prefers to design their own unique e-commerce packaging and organize individual tomato farm tours, according to interviewees (face-to-face interview on April 11, 2015). In addition, this increasingly popular and successful e-commerce model attracts many people of the younger generation to become involved in the tomato farming business. However, to better brand their products, the tomato farmers also join the annual "orange-flavored tomato" festival that occurs near the Chinese New Year or the "One Day Farm" that is organized by the local government. Agritourism offers numerous possibilities for the unintentional realization of strategies or emergent strategies, which Mintzberg argued in 1978.

\subsection{Outcome of State-led Coopetition}

One major difference this study finds between firm-initiated coopetition and state-led coopetition is in their overall outcomes and impacts on society. Government is essentially a public institution. All state-led programs are paid by taxpayer money, not by capital funding from private actors. When spending public money, public value production is usually expected by the general public. Researchers are also exploring how the public sector can better create public value to fulfill public interests (Moore, 1995, 2013; Kelly \& Muers, 2002; Bozeman, 2007; Rhodes \& Wanna, 2007). In the same logic, the four state-led coopetition cases were created by using public funds. As a result, in addition to generating extra income for the farmers in each community, the public-private partnership programs also create public value, such as cultural preservation, elderly welfare, food safety, price stabilization, youth employment training and eco-diversity protection (see Table 5's words in bold font). These public values are seldom the deliberate focus or outcome of private entities if they have formed intentional coopetition from the single and primary motivation to create profit.

Table 5. Comparative impacts of state-led coopetition

\begin{tabular}{|c|c|c|c|c|}
\hline & $\begin{array}{l}\text { Case } 1 \\
\text { Meinong District } \\
\text { Jhong-zun } \\
\text { community }\end{array}$ & $\begin{array}{l}\text { Case } 2 \\
\text { Dashu District } \\
\text { Nong-mu } \\
\text { community }\end{array}$ & $\begin{array}{l}\text { Case } 3 \\
\text { Cishan District } \\
\text { Jhong-liao } \\
\text { community }\end{array}$ & $\begin{array}{l}\text { Case } 4 \\
\text { Cishan District } \\
\text { Nan-sheng } \\
\text { community }\end{array}$ \\
\hline $\begin{array}{l}\text { Role of } \\
\text { the State }\end{array}$ & $\begin{array}{l}\text { - offer farming technique } \\
\text { training/course/workshop } \\
\text { to young farmers } \\
\text { - place-based marketing } \\
\text { - branding and preserving } \\
\text { Hakka culture and } \\
\text { agricultural products } \\
\text { - agritourism } \\
\text { - stabilize radish prices } \\
\text { by centrally controlling } \\
\text { quantity and quality }\end{array}$ & $\begin{array}{l}\text { - link alliance } \\
\text { - place-based } \\
\text { marketing } \\
\text { - branding and } \\
\text { preserving more } \\
\text { than } 100 \text { years of } \\
\text { pineapple farming } \\
\text { culture and } \\
\text { lifestyle } \\
\text { - coordinate or pool } \\
\text { resource for } \\
\text { agritourism } \\
\text { - encourage } \\
\text { cooperative farming } \\
\text { to ensure quality } \\
\text { and trust among } \\
\text { farmers to stabilize } \\
\text { prices }\end{array}$ & $\begin{array}{l}\text { - issue community } \\
\text { large-word newsletter } \\
\text { for elderly that is } \\
\text { subsidized by the } \\
\text { Ministry of Labor } \\
\text { - branding, logo } \\
\text { design } \\
\text { - use rural } \\
\text { revitalization project } \\
\text { to build more } \\
\text { infrastructure } \\
\text { - assist residents to } \\
\text { acquire more public } \\
\text { grants for } \\
\text { eco-diversity } \\
\text { appreciation or } \\
\text { educational camping } \\
\text { equipment to promote } \\
\text { agritourism }\end{array}$ & $\begin{array}{l}\text {-scale alliance } \\
\text {-link alliance } \\
\text { - Agricultural } \\
\text { Bureau establishes } \\
\text { e-commerce } \\
\text { platform } \\
\text { - provide financial } \\
\text { support for } \\
\text { organizing training } \\
\text { for handcraft by } \\
\text { lychee wood for } \\
\text { recycling } \\
\text { education } \\
\text { purposes } \\
\text { - pesticide control } \\
\text { training to ensure } \\
\text { food safety } \\
\text { - promote rural } \\
\text { life cultural } \\
\text { appreciation }\end{array}$ \\
\hline
\end{tabular}




\begin{tabular}{|c|c|c|c|c|}
\hline $\begin{array}{l}\text { Impact of } \\
\text { State-led } \\
\text { Coopetiti } \\
\text { on }\end{array}$ & $\begin{array}{l}\text { Private value: increase } \\
\text { farmers' income } \\
\text { Public value: } \\
\text { - Hakka cultural } \\
\text { preservation } \\
\text { - price stabilization } \\
\text { - food quality control }\end{array}$ & $\begin{array}{l}\text { Private value: } \\
\text { increase farmers' } \\
\text { income } \\
\text { Public value: } \\
\text {-> } 100 \text { years of } \\
\text { pineapple growing } \\
\text { lifestyle culture } \\
\text { appreciation and } \\
\text { preservation } \\
\text { - price stabilization } \\
\text { - food quality } \\
\text { control } \\
\text { - social capital } \\
\text { building }\end{array}$ & $\begin{array}{l}\text { Private value: } \\
\text { increase farmers' } \\
\text { income } \\
\text { Public value: } \\
\text { - elderly welfare } \\
\text { service } \\
\text { - rural revitalization } \\
\text { - eco-diversity } \\
\text { preservation and } \\
\text { appreciation } \\
\text { - big cart drum array } \\
\text { cultural preservation } \\
\text { - children's natural } \\
\text { science education } \\
\text { through camping }\end{array}$ & $\begin{array}{l}\text { Private value: } \\
\text { increase farmers' } \\
\text { income } \\
\text { Public value: } \\
\text { - recycling } \\
\text { education } \\
\text { - food safety } \\
\text { - rural life cultural } \\
\text { appreciation }\end{array}$ \\
\hline
\end{tabular}

Source: Summarized by author from the interviewees

In this study, the role that the public sector plays in coopetition, as shown in the above table, varies among the communities. The Kaohsiung city government has used the scale or link alliance strategy (Dussauge et al., 2004) to promote agritourism through the "One Day Farmer" public-private partnership program since 2013. In all four sample communities, farmers are invited to contribute similar resources to achieve scale advantages. However, only in three of the four communities, different farmers or farming-related firms were invited by public institutions to contribute complimentary resources to achieve link alliance advantages. Moreover, the diversity of public value that is created by each state-led coopetition also reflects the individual local community's distinguished historical, environmental and social development.

The focus of promoting agricultural coopetition is often linked with the preservation of Hakka culture in Case 1. The public sector in Case 2 also strives to accumulate more social capital such as trust among farmers and preserve more than one hundred years of pineapple farming culture and lifestyle in its public-private collaborative coopetition program. Cases 3 and 4 promote eco-diversity and children's natural science education through annual camping programs and recycling and rural life appreciation education. In the mountainous land of the Jhong-liao community, a recent college graduate staff member, who was funded by a rural revitalization program under the Soil and Water Conservation Bureau of the central government, initiated a two-day, one-night camping program in 2014. By spending time in the community, this program invited both residents and tourists to appreciate the ecosystem of this undisturbed region away from the city. A native land turtle and endangered owl watch, insect and bird identification and landscape appreciation are included in the guided tour. Moreover, the government-funded staff member also introduced a "big cart drum array" performance to the camping agenda. The camping program participants were invited to experience this traditional drum performance, which in the past, occurred only on God's birthday but was gradually forgotten because of population loss in the village (May 29, 2015 face-to-face interview).

Overall, state-led coopetition is also a more participatory and collaborative style of coopetition business model. The public-private partnership programs often involve multiple actors from not only the public sector but also from private business, non-governmental organizations, the media, schools, etc. The public institution in these programs acts as a societal entrepreneur (Berglund et al., 2012) to first change the rules from a zero-sum game to a variable-sum game in Taiwan's rural areas. Second, these public institutions create additional public value that is impossible without the financial support and coordination of government.

\section{Concluding Discussion}

This research began by asking what can governments do when they face the challenges that are caused by the liberalization trend of global trade, especially in the agricultural sector. In the post-WTO era, one experimental solution that was introduced by the local government in Kaohsiung, Taiwan was to replicate a "state-led coopetition" program in rural areas, which is called "One Day Farmer". Since 2013, this public-private partnership program has successfully invited traditionally competing actors in villages to cooperate and thus attract thousands of Chinese tourists to southern Taiwan to experience farming life. Accordingly, this project has revitalized approximately 40 rural communities. However, were these state-led coopetition programs conducted similarly to conventional 
firm-initiated coopetition programs? What is the role that the public sector played in these public-private partnership coopetitions?

This study carefully analyzed the initiation, process and impact of state-led coopetition programs that were launched in the four illustrative communities in the Kaohsiung rural area. From this analysis, this study yields the following four major findings to advance coopetition theory building: 1) crises are focusing events to induce coopetition behavior; 2) competing firms in state-led coopetition cooperate and compete differently than in a typical business environment; 3) not all coopetition that is led by the public sector is unintentional; and 4) state-led coopetition generates extra public value.

First, in this comparative case study, the general impact of crisis on changing firm behavior can be observed. This crisis-as-a-focusing-event finding in state-led coopetition is not different from traditional coopetition that is initiated by firms to seek breakthroughs out of stalemates (Carfi \& Schiliro 2011; Katsanakis et al., 2011). However, the way that firms compete and cooperate in state-led coopetition programs is different. Contrary to the traditional business environment (Walley, 2007), with governmental intervention, three of the four state-led coopetition cases demonstrated more cooperation in the downstream activities than in the upstream activities. Moreover, this study also shows that not all coopetition that is led by the public sector is so-called "emergent coopetition" as opposed to the deliberate coopetition that is led by firms (Mintzberg \& Waters 1985; Mariani, 2007). Both intentional and unintentional models are found in the four public-private partnership coopetition cases. Finally, this empirical research shows that a principal difference between firm-led coopetition and state-led coopetition lies in the outcome and its impact on society. Firm-led coopetition emphasizes private value return, whereas state-led coopetition creates extra public value in addition to collective private value gain. The government in state-led coopetition plays the role of societal entrepreneur not only by changing the rules of the business game but also by engaging in value changing activities.

\section{References}

Albert, S. (1999). E-Commerce Revitalizes 'Co-Opetition'. Computerworld, 33(15), 36.

Astley, W. G., \& Fombrun, C. J. (1983). Collective Strategy: The Social Ecology of Organizational Environments. Academy of Management Review, 8(4), 576-587. http://dx.doi.org/10.5465/AMR.1983.4284657

Baggio, R., Czakon, W., \& Mariani, M. M. (2013). Managing Tourism in a Changing World. London: Routledge.

Bagshaw, M., \& Bagshaw, C. (2001). Co-opetition Applied to Training-A Case Study. Industrial and Commercial Training, 33(5), 175-177. http://dx.doi.org/10.1108/00197850110398945

Bengtsson, M., \& Kock, S. (2000). "Coopetition" in Business Networks-To Cooperate and Compete Simultaneously. Industrial Marketing $\quad$ Management, $29(5), \quad$ 411-425. http://dx.doi.org/10.1016/S0019-8501(99)00067-X

Berglund, K., Johannisson, B., \& Schwartz, B. (Eds.) (2012). Societal Entrepreneurship: Positioning, Penetrating, Promoting. Cheltenham: Edward Elgar Publishing.

Birkland, T. A. (1998). Focusing Events, Mobilization, and Agenda Setting. Journal of Public Policy, 18(1), 53-74. http://dx.doi.org/10.1017/S0143814X98000038

Birkland, T. A. (2006). Lessons of Disaster: Policy after Catastrophic Events. Washington, DC: Georgetown University Press.

Boivin, C. A. (1987). Public-Private Sector Interactions in Canada, Travel and Tourism: Thrive or Survive. Conference Proceedings, pp. 147-50. Salt Lake City: Travel and Tourism Research Association.

Bozeman, B. (2007). Public Values and Public Interest: Counterbalancing Economic Individualism. Washington D.C.: Georgetown University Press.

Brandenburger, A., \& Stuart, H. (2007). Biform Games. Management Science, 53(4), 537-549. http://dx.doi.org/10.1287/mnsc. 1060.0591

Carfi, D., \& Schiliro, D. (2011). Crisis in the Euro Area. Coopetitive Game Solutions as New Policy Tools. Theoretical and Practical Research in Economic Fields, 1(3), 23-36.

Chu, S. (2001). Impact of WTO on Agricultural Industry: Cases of Tainan, Kaohsiung and Pintung Counties. NPF Research Report. (Chinese)

Contractor, F., \& Lorange, P. (1988). Why should firms co-operate? The Strategy and Economics Basis for 
Co-operative Ventures. In F. Contractor and P. Lorange (Eds.), Co-operative Strategies in International Business: Joint Ventures and Technology Partnerships between Firms. San Francisco: New Lexington Press.

Corbin, T. B. (2010). Policy Entrepreneurs and Focusing Events: Congressional Agenda Setting after Hurricane Katrina. Claremont: The Claremont Graduate University.

Cringely, R. X. (2002). A Peaceful Coexistence. Infoworld, 24(15), 12.

Dussauge, P., Garrette, B., \& Mitchell, W. (2004). Asymmetric Performance: the Market Share Impact of Scale and Link Alliances in the Global Auto Industry. Strategic Management Journal, 25(7), 701-711. http://dx.doi.org/10.1002/smj.416

Ellinger, A. E. (2000). Improving Marketing/Logistics Cross-Functional Collaboration in the Supply Chain. Industrial Marketing Management, 29(1), 85-96. http://dx.doi.org/10.1016/S0019-8501(99)00114-5

Hamel, G., Doz, Y. L., \& Prahalad, C. K. (1989). Collaborate with Your Competitors and Win. Harvard Business Review, 67(1), 133-139.

Harrison, G. W., Rutherford, T. F., \& Tarr, D. G. (1997). Quantifying the Uruguay Round. The Economic Journal, 107(444), 1405-1430.

Hathaway, D. E., \& Ingco M. D. (1995). Agricultural Liberalization and the Uruguay Round. In World Bank Discussion Papers, pp. 1-24.

Huang, C. H. (2008). Simulation Analysis of Trade Remedy Measures on Injury of Taiwan's Agricultural Industry after Accession to WTO: A Case Study of Adzuki Beans Industry. Taiwanese Agricultural Economic Review, $13(2), 135-164$.

Huang, J. C. (2009). The Study of the Recreational Experience Satisfaction on the Tourist Participation of Pineapple and Litchi Cultural Tour Season in Kaohsiung County in 2009. Journal of Tung Fang Institute of Technology, 30, 58-95.

Inkpen, A. C. (1996). Creating Knowledge through Collaboration. California Management Review, 39(1), 123-140. http://dx.doi.org/10.2307/41165879

Jorde, T. M., \& Teece, D. J. (1989). Competition and Cooperation: Striking the Right Balance. California Management Review, 31(3), 25-37. http://dx.doi.org/10.2307/41166568

Juhel, M. H. (2000). Globalization, Partnerships in Ports: Trends for the 21st Century. Ports and Harbours, 45(5), 9-14.

Katsanakis, I., Kossyva, D., \& Vorria, E. (2011). Co-Opetition Strategy in Business Excellence: Confronting the Economic Crisis. Proceedings of 14th QMOD-ICQSS Conference on Quality and Service Sciences.

Kelly, G., \& Muers, S. (2002). Creating Public Value: An Analytical Framework for Public Service Reform. Strategy Unit, Cabinet Office, UK Government. Retrieved from http://www.strategy.gov.uk

Kingdon, J. W. (1984). Agendas, Alternatives and Public Policy. Boston, MA: Little Brown.

Kusunoki, K. (2004). Value Differentiation: Organizing 'Know-What' for Product Concept Innovation. In H. Takeuchi and I. Nonaka (Eds.), Hitotsubashi on Knowledge Management. Singapore: John Wiley \& Sons.

Kylänen, M., \& Mariani, M. M. (2012). Unpacking the Temporal Dimension of coopetition in Tourism Destinations: Evidence from Finnish and Italian Theme Parks. Anatolia, 23(1), 61-74. http://dx.doi.org/10.1080/13032917.2011.653632

Kylänen, M., \& Rusko R. (2011). Unintentional coopetition in the Service Industries: the Case of Pyhä-Luosto Tourism Destination in the Finnish Lapland. European Management Journal, 29(3), 193-205. http://dx.doi.org/10.1016/j.emj.2010.10.006

Lado, A. A., Boyd N. G., \& Hanlon, S. C. (1997). Competition, Cooperation, and the Search for Economic Rents : A Syncretic Model. Academy of Management Review, 22(1), 110-141. http://dx.doi.org/10.5465/AMR.1997.9707180261

Ma, T. C., \& Fu, C. H. (2008). The Preliminary Investigation of the Production and Labor Process of Organic Agriculture in Taiwan. Bulletin of Labour Research, 23, 57-112.

Mariani, M. (2007). Coopetition as an Emergent Strategy: Empirical Evidence from an Italian Consortium of Opera Houses. International Studies of Management \& Organization, 37(2), 97-126. 
http://dx.doi.org/10.2753/IMO0020-8825370205

Martin, W. (1996). The Uruguay Round and the Developing Countries. Press: Cambridge University.

McNiel, D. E. (1997). United States' Agricultural Protectionism After the Uruguay Round: What Remains of Measures to Provide Relief from Surges of Agricultural Imports. North Carolina Journal of International Law and Commercial Regulation, 23(2), 281-311.

Mintzberg, H. (1978). Patterns in Strategy Formation. Management Science, 24(9), 934-948. http://dx.doi.org/10.1287/mnsc.24.9.934

Mintzberg, H., \& Waters, J. A. (1985). Of Strategies, Deliberate and Emergent. Strategic Management Journal, 6(3), 257-272. http://dx.doi.org/10.1002/smj.4250060306

Moore, M. (1995). Creating Public Value. Cambridge, MA: Harvard University Press.

Moore, M. H. (2013). Recognizing Public Value. Cambridge, MA: Harvard University Press.

Moss, T., \& Bannon, A. (2004). Africa and the Battle over Agricultural Protectionism. World Policy Journal, 21(2), 53-61.

Nalebuff, B. J., \& Brandenburger, A. M. (1997). Co-opetition: Competitive and Cooperative Business Strategies for the Digital Economy. Strategy \& Leadership, 25(6), 28-33. http://dx.doi.org/10.1108/eb054655

Naoi, M., \& Kume, I. (2011). Explaining Mass Support for Agricultural Protectionism: Evidence from a Survey Experiment during the Global Recession. International Organization, 65(4), 771-795. http://dx.doi.org/10.1017/S0020818311000221

Potter, C., \& Burney, J. (2002). Agricultural Multifunctionality in the WTO-Legitimate Non-Trade Concern or Disguised Protectionism?. Journal of Rural Studies, 18(1), 35-47. http://dx.doi.org/10.1016/S0743-0167(01)00031-6

Rhodes, R. A. W., \& Wanna, J. (2007). The Limits to Public Value, or Rescuing Responsible Government from the Platonic Guardians. Australian Journal of Public Administration, 66(4), 406-421. http://dx.doi.org/10.1111/j.1467-8500.2007.00553.x

Ritala, P., Välimäki, K., Blomqvist, K., \& Henttonen, K. (2009). Intrafirm coopetition, Knowledge Creation and Innovativeness. Co-Opetition Strategy-Theory, Experiments and Cases, (2009), 64-73.

Schott, J. J., \& Buurman, J.W. (1994). Uruguay Round: An Assessment. Washington, DC: Institute for International Economics.

Selin, S., \& Chavez, D. (1995). Developing an Evolutionary Tourism Partnership Model. Annals of Tourism Research, 22(4), 844-856. http://dx.doi.org/10.1016/0160-7383(95)00017-X

Stevens, B. (1988). Co-Operative Activities in Competitive Markets. Tourism Research: Exploring Boundaries. Montreal: Travel and Tourism Research Association, pp. 139-141.

Tapscott, D., \& Williams, A. D. (2006). Wikinomics. How Mass Collaboration Changes Everything. London: Portfolio, Penjuin Group.

Thomason, S. J., Simendinger, E., \& Kiernan, D. (2013). Several Determinants of Successful coopetition in Small Business. Journal of Small Business \& Entrepreneurship, 26(1), 15-28. http://dx.doi.org/10.1080/08276331.2012.761800

Tidström, A. (2008) Perspectives on coopetition on Actor and Operational Levels. Management Research: Journal of the Iberoamerican Academy of Management, 6(3), 207-217. http://dx.doi.org/10.2753/JMR1536-5433060304

Ting, W. Y. (2011). Taiwan Farmer's Movement. Agricultural Extension Anthology, 56, 281-290.

Walley, K. (2007). Coopetition: an Introduction to the Subject and an Agenda for Research. International Studies of Management \& Organization, 37(2), 11-31. http://dx.doi.org/10.2753/IMO0020-8825370201.

Wang, C. H. (2002). The Changing Role of the Agricultural Extension under the WTO Rules - Comparative Analysis in Taiwan and Japan. Yuan: Council of Agriculture, Executive.

Wilkinson, I., \& Young, L. (2002). On Cooperating: Firms, Relations and Networks. Journal of Business Research, 55(2), 123-132. http://dx.doi.org/10.1016/S0148-2963(00)00147-8 


\section{Notes}

Note 1. Ten years later, Brandenburger and Stuart (2007) further elaborated on coopetition as a strategy that is played in a hybrid non-cooperative-cooperative game - a "biform game" that creates favorable economic conditions for the players.

Note 2. These data and documents were provided by the Council of Agriculture, Executive Yuan, Republic of China in Taiwan at http://www.coa.gov.tw/view.php?catid=4270 (accessed Dec. 15, 2015).

Note 3. http://agri.cocker.com.tw/upload/default1.asp (accessed on Dec. 18, 2015)

Note 4. Liberty Times Net Oct. 22, 2015 http://news.ltn.com.tw/news/local/paper/925909 (accessed on Dec. 18, 2015)

Note 5. One day coffee farm Nov. 20, $2015 \quad$ United Daily News http://udn.com/news/story/7326/1325906-\%E4\%B8\%80\%E6\%97\%A5\%E8\%BE\%B2\%E5\%A4\%AB\%E7\%A8\%AE $\%$ E5\%92\%96\%E5\%95\%A1 (accessed on Dec. 18, 2015)

Note 6. https://play.niceday.tw/product/973 (accessed Dec. 18, 2015)

Note 7. For more data and historical facts, please visit the Meinong District Office in Kaohsiung City at http://meinong-district.kcg.gov.tw/? (accessed on Dec. 17, 2015).

Note 8. The historical data and facts can be found in the Dashu District Office in Kaohsiung City at http://dashu.kcg.gov.tw/ananas/ananas1.htm (accessed on Dec. 17, 2015).

Note 9. For more information, please refer to the Executive Yuan Council of Agriculture, Soil and Water Conservation Bureau at http://rural.swcb.gov.tw/Rural/Detail/511.

Note $\quad 10 . \quad$ United $\quad$ Daily $\quad$ News $\quad$ Dec. $\quad 17, \quad 2015$. http://udn.com/news/story/1/1384127-\%E9\%9B\%B2\%E6\%9E\%97\%E7\%AB\%8B\%E5\%A7\%94\%E2\%95\%B1\%E6 \%86\%82TPP\%Е8\%A1\%9D\%E6\%93\%8A\%E8\%BE\%B2\%E6\%A5\%AD-\%E5\%80\%99\%E9\%81\%B8\%E4\%BA\%B А $\%$ Е5\%BC\%B5\%Е9\%8E\%94\%Е9\%BA\%92\%ЕF\%BC\%9A\%E5\%8F\%AF\%Е8\%88\%89\%E8\%BE\%A6\%E5\%85 $\% \mathrm{AC} \% \mathrm{E} 6 \% 8 \mathrm{~A} \% 95$ (accessed on Dec. 18, 2015)

Note 11. ETToday news June 19, 2012 http://www.ettoday.net/news/20120619/61481.htm

Note 12. News on June 3, 2003 http://www.newtaiwan.com.tw/bulletinview.jsp?bulletinid=14701 (accessed on Dec. 18, 2015)

Note 13. Post Mall is an online shopping platform that is operated by the state-owned Postal Office and covers more than 1,700 stores (http://postmall.post.gov.tw/postmall/).

Note 14. Hakka Affairs Council government website 2016 Hakka Twelve Festival http://www.hakka.gov.tw/ct.asp?xItem=138885\&ctNode=2428\&mp=1 (accessed on Dec. 19, 2015) 